
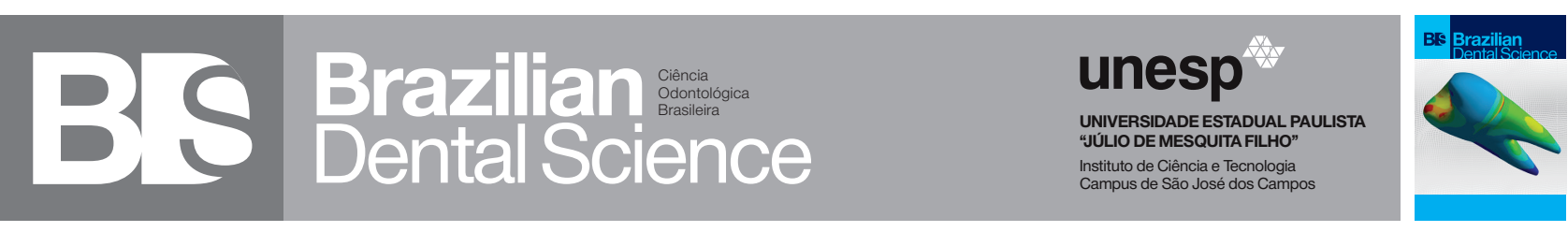

\title{
Push-out bond strength of glass fiber posts luted with two resin cements
}

\author{
Resistência à tração de pinos de fibra de vidro cimentados com dois tipos de cimento resinoso
}

Blanca Liliana Torres LEÓN ${ }^{1}$, Vitor Lopes FRANCO ${ }^{2}$, Emily Vivianne Freitas da SILVA ${ }^{3}$, Leonardo MUNIZ ${ }^{2}$, Fernando Carneiro RIBEIRO $^{4}$

1 - Department of Prosthodontics - Bahia Federal University (UFBA) - Salvador - BA - Brazil.

2 - Department of Prosthodontics - Bahiana School of Medicine and Public Health - Salvador - BA - Brazil.

3 - Department of Dental Materials and Prosthodontics - Aracatuba Dental School - Univ. Estadual Paulista (UNESP) - Aracatuba - SP Brazil.

4 - Department of Prosthodontics - State University of Feira de Santana (UEFS) - Feira de Santana - BA - Brazil.

\begin{abstract}
Objectives: To evaluate the bond strength of a prefabricated glass fiber post to the root dentin with two resin cements using the push-out test. Material and Methods: Thirty fiber posts (White Post ECD) were cemented in human endodontically treated anterior teeth with two resin cements $(n=15)$ : RelyxTM ARC and AllCem. The roots were transversely sectioned and divided in cervical, middle and apical thirds after $48 \mathrm{~h}$ of cementation. The specimens' retention was tested by push-out method. The results were analyzed by 2 -way ANOVA and Tukey's test $(\mathrm{p}<0.05)$. Results: There were no significant differences in the bond strength between the resin cements. The bond strength was higher in cervical third than in middle and apical thirds for both resin cements. It was observed higher percentages of adhesive failures followed by mixed. Conclusions: Both resin cements are indicated in the cementation of glass fiber post.
\end{abstract}

\section{KEYWORDS}

Dental prosthesis; Post and core technique; Biomechanical phenomena.

\section{RESUMO}

Objetivo: Avaliar a resistência de união entre dentina radicular e pino pré-fabricado, utilizando dois sistemas cimentantes, por meio do teste push-out. Material e Métodos: Trinta pinos de fibra de vidro (White Post DCE) foram cimentados a dentes humanos anteriores, tratados endodonticamente, com o auxílio de dois sistemas cimentantes $(n=15)$ : RelyxTM ARC e AllCem. Após 48 horas da cimentação, as raízes foram seccionadas transversalmente e divididas em terços cervical, médio e apical. Os corpos-de-prova foram submetidos ao teste de cisalhamento por extrusão "push-out". Os resultados foram submetidos aos testes estatísticos de análise de variância (2-way ANOVA) e de Tukey $(\mathrm{p}<0,05)$. Resultados: Não houve diferença estatisticamente significativa na resistência de união entre os dois cimentos resinosos utilizados. A resistência de união foi maior no terço cervical do que nos terços médio e apical. Foi observada maior frequência de falhas adesivas seguida das mistas. Conclusão: Os dois cimentos resinosos são sugeridos para a cimentação de pinos de fibra de vidro.

\section{PALAVRAS-CHAVE}

Prótese dentária; Técnica para retentor intrarradicular; Fenômenos biomecânicos. 


\section{INTRODUCTION}

$\mathrm{T}$ he post and core technique has been used for the restoration of endodontic treated teeth for the last 250 years [1,2]. Posts and core can replace lost dental structure, provide support and retention for prosthetic crowns [35]. There are important concerns about post and core restorations, i.e. treatment prognosis, capacity to support stresses, difficulty of removal and compatibility of posts with restorative materials [5].

Besides, the post core should proper transfer stresses to the tooth, avoiding root weakness, which reduces fracture resistance, or loss of retention between post and root canal dentin [6-8]. To date, the association of a resin cement to glass fiber post reduces post fractures and provides a better distribution of stress to the remaining tooth structure because both have an elasticity modulus similar to dentin. Additionally, glass fiber posts are indicated for aesthetic restorations because their color is similar to the tooth and do not oxidize [2-4,9].

One of the major concerns regarding prefabricated glass fiber posts is the bonding mechanism among post, resin cement and root canal dentin $[7,9,10]$. The histological and anatomical characteristics of the post space associated with the different properties of resin cements available in dental market may influence post cementation. There are many variables that can affect adhesion in the post-cement-dentin interface, i.e. previous exposition of the root canal to sodium hypochlorite, hydrogen peroxide, EDTA; polymerization shrinkage of the resin cement; an unfavorable post space; properties of the glass fiber post; presence of gutta percha residuals; endodontic cement; and smear layer and microorganisms closing the dentin tubules [10-16].

Another variable that can affect the postcement-dentin interface is the mechanical properties of resin cements. There are many resin cements available in dental market. They differ from each other regards the handling, the composition and mechanical properties, as polymerization mode and flexural resistance $[9,17,18]$.

Some studies affirm that the bond strength vary according to the three levels of the root canal $[6,8,9,19]$. There are many unclear aspects regarding resin cements in the root canal dentin, mainly in the areas with low light transmission, such as medium and apical third of the root $[11,20]$. This study aimed to evaluate the pushout bond strength of a glass fiber post and two dual-resin cements in different thirds of the root (cervical, medium and apical) and analyze adhesion in the post-cement-dentin interface. The hypothesis of this study was that the two resin cements provided proper cementation of glass fiber post, regarding the push-out bond strength.

\section{MATERIAL AND METHODS}

Healthy permanent anterior teeth with similar diameters and lengths were used in this study. Teeth selected were extracted for periodontal or orthodontic reasons and obtained from the Tooth Bank of Dentistry Schools and health centers after the patient signed a donation term and an informed consent form. Teeth were stored in thymol $0.2 \%$ before the experimental tests [21]. Initial radiographies of the specimens were obtained to verify cracks, obliterations or internal root canal dentin resorption. The materials used in this study are listed in Table I. 
Table I - Commercial brand, composition, type and manufacturer of materials used in this study

\begin{tabular}{|c|c|c|c|}
\hline Material & Composition* & Type & Manufacturer \\
\hline White Post DCE® & Glass fiber post, resin matrix, silane and inorganic filler content. & Glass fiber posts & FGM \\
\hline Relyx ${ }^{\mathrm{TM}} \mathrm{ARC}$ & $\begin{array}{l}\text { Paste A: Bis-GMA, TEGDMA, zirconia, silica, pigments and photo-initiator systems. } \\
\text { Paste B: Bis-GMA, TEGDMA, zirconia, silica and benzoyl peroxide. }\end{array}$ & Dual-resin cement & 3M-ESPE \\
\hline AllCem & $\begin{array}{c}\text { Base paste: TEGDMA, Bis EMA, Bis GMA, camphorquinone, co-initiators, barium } \\
\text { alumino-silicates, silicon dioxide inorganic pigments and preservatives. } \\
\text { Initiator paste: methacrylic monomers, benzoyl peroxide and stabilizers, and barium } \\
\text {-alumino-silicates. }\end{array}$ & Dual-resin cement & FGM \\
\hline $\begin{array}{l}\text { Adper }{ }^{\mathrm{TM}} \text { Scotchbond } \\
\text { Multi-Use Plus }\end{array}$ & $\begin{array}{l}\text { Initiator: an ethanol solution of a salt of sulfinic acid component and curing unit } \\
\text { Primer:HEMA, polialkenoic acid } \\
\text { Catalyst:Bis-GMA, HEMA, benzoyl peroxide. }\end{array}$ & Self-curing adhesive & 3M-ESPE \\
\hline
\end{tabular}

${ }^{*}$ Obtained from manufacturer.

The coronal third of the teeth was sectioned with a diamond disk (\#7020, KG Sorensen Ind, Barueri, Sao Paulo, Brazil) at low-speed and constant irrigation at the enamel-cement junction. One operator endodontically treated the roots. The removal of gutta percha and the endodontic obturation were performed with a sequence of Largo Peeso Reamer \#2 and \#3 (Dentsply-Maillefer, Petropolis, Rio de Janeiro, Brazil) followed by \#0.5E, \#1E, and \#2E burs of White Post DEC system creating a post space with a depth of $4 \mathrm{~mm}$ minus the length of the final obturation [22].

After the root canals preparation, thirty specimens were divided in two groups $(n=15)$, according to the resin cement: Relyx ${ }^{\mathrm{TM}} \mathrm{ARC}$ and AllCem. The groups were divided in three thirds (cervical, medium and apical), resulting in 6 subgroups. The root specimens were etched with phosphoric acid gel 37\% for 15 seconds, washed with distilled water and dried with air jets for 5 seconds and with absorbent paper cones \#70. Before cementation, the glass fiber posts were cleaned with phosphoric acid gel 37\% and an application of silane (FGM Joinville, Santa Catarina, Brazil) was performed for 60 seconds and air-dried for 5 seconds.

Then, resin cements were manipulated according to instructions of the respective manufacturer. For both cements, the required amount of cement in a 1:1 ratio was dispensed into a mixing block. The cement was mixed for 10 seconds and then applied in the root canal from the apical to the cervical portion. The post was inserted, verifying the correct its positioning, and eventual cement excesses were removed. The photopolymerization was performed on occlusal surface for 40 seconds to guarantee maximum bond strength at the edges.

After the cementation of glass fiber posts, root specimens were stored in an environment of $100 \%$ of humidity at $37^{\circ} \mathrm{C}$ for $24 \mathrm{~h}$. The specimens were immersed in distilled water at $37^{\circ} \mathrm{C}$ for $24 \mathrm{~h}$ in an incubator [12]. The apical third was sectioned with a diamond disk (\#7020, KG Sorensen Ind, Barueri, Sao Paulo, Brazil) with constant irrigation, with a standard length of the remaining specimen of $9 \mathrm{~mm}$. Then, the specimens were transversally sectioned in three thirds (cervical, medium and apical) of a standard length of $2.8 \mathrm{~mm}$. The thirds were sequentially polished with 320-, 400- and 600-grit sandpapers (320, 400 e 600-Norton $\AA$, Sao Paulo, Brazil) in a polishing machine (Arotec-APL-4; Arotec S.A., Sao Paulo, Brazil) for the flatting of the surface and to a thickness of $2.7 \mathrm{~mm}$ measured by a digital caliper (Mitutoyo 500-144, Kawasaki, Japan).

After the cementation of the glass fiber posts, specimens were submitted to the push-out 
bond strength test in an universal testing machine (modelo DL-2000, EMIC, Parana, Brazil) with a load of $50 \mathrm{Kgf}$. A metallic bar with an active tip was fixed in the universal testing machine and positioned in the center of the glass fiber post. The push-out bond strength was performed at a crosshead of $0.5 \mathrm{~mm} / \mathrm{min}$ until the debonding of the glass fiber post. The maximum force value (Newton, N) was divided by the bonding surface area and calculated by the following formula:

$$
\begin{aligned}
& \mathrm{A}=2 \pi \mathrm{rh} \pi=\text { Constant of } 3.14 \\
& \mathrm{r}=\text { Glass fiber post radius } \\
& \mathrm{h}=\text { thickness of specimen. }
\end{aligned}
$$

The bonding failures were visually analyzed with a stereomicroscope (Lambda LEE2, Atto Instruments Co.,Hong Kong, China) with $\times 40$ magnification and classified as: adhesive in the cement-post interface (C-P), adhesive in the cement-dentin interface (C-D), cohesive in the cement $(\mathrm{C})$ or in the post $(\mathrm{P})$ and mixed failure (combination of the types of failures mentioned above) [23].

The results were submitted to the two-way analysis of variance (ANOVA) and Tukey test $(\mathrm{p}<0.05)$ considering the factors "Resin cement" and "Root third".

\section{RESULTS}

The mean results (MPa) of push-out bond strength of cervical, medium and apical thirds are presented in Table II. The cervical third showed the highest mean results than other thirds.

Table II - Means results \pm standard deviation of push-out bond strength $(\mathrm{MPa})$ in cervical, medium and apical thirds regarding the two resin cements (Allcem and Relyx ${ }^{\mathrm{TM}} \mathrm{ARC}$ ) tested

\begin{tabular}{|cccc|}
\hline & CervicalThird & Medium Third & Apical Third \\
\hline AllCem & $9.95 \pm 4.26 \mathrm{a}$ & $7.22 \pm 1.88$ & $5.08 \pm 2.20$ \\
\hline Relyx ${ }^{\mathrm{TM}}$ ARC & $9.82 \pm 6.54$ & $8.82 \pm 6.75$ & $6.9 \pm 6.60$ \\
\hline
\end{tabular}

Analysis of variance showed no statistical significant difference to the interaction between factors "Resin cement" and "Root third" ( $\mathrm{p}=0.88)$, or to the main factor "Resin cement" $(\mathrm{p}=0.85)$. Statistical significant difference was observed to factor "Root third" ( $p<0.001$ ). The means results and standard deviations of bond strength among the different thirds are presented in Table III. Regarding the two resin cements, bond strength was higher in the cervical third $(9.88 \pm 5.67$ $\mathrm{MPa})$ than in medium and apical thirds $(7.2 \pm$ 3.10 MPa and 5.2 $\pm 3.08 \mathrm{MPa}$ ).

Table III - Means, standard deviation and Tukey test of pushout bond strength (MPa) for multiple comparisons of means according to the different thirds of the root canal

\begin{tabular}{|cccc|}
\hline Third & Mean & $\begin{array}{c}\text { Standard } \\
\text { deviation }\end{array}$ & $\begin{array}{c}\text { Tukey } \\
(\mathbf{\alpha}=\mathbf{0 . 0 5})\end{array}$ \\
\hline Cervical & 9.8844444 & 5.6665037 & $\mathrm{~A}$ \\
\hline Medium & 7.2388462 & 3.1041344 & $\mathrm{~B}$ \\
\hline Apical & 5.2552174 & 3.0821360 & $\mathrm{~B}$ \\
\hline
\end{tabular}

Means with different letters differ significantly according to the Tukey test $(p<0.05)$.

Besides the push-out bond strength of canal root dentin to glass fiber post, the visual analysis was performed regarding the type of failure of post-resin cement interface. The results of this analysis are presented in Figure 1. It can be observed that the majority of interfaces exhibited C-D adhesive failures followed by mixed failures.

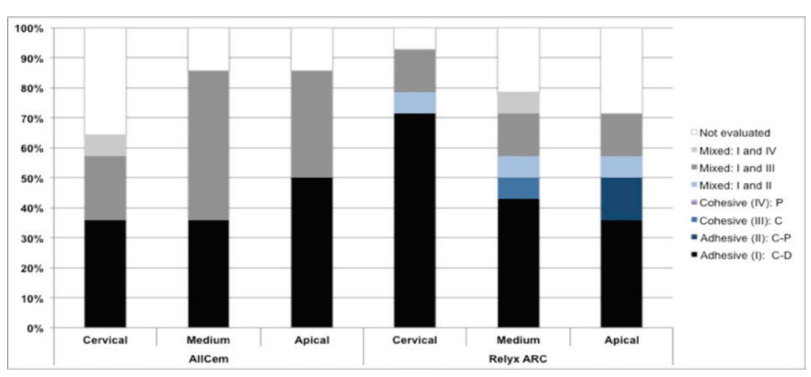

Figure 1 - Percentage (\%) of failures according to root thirds and resin cements 


\section{DISCUSSION}

The hypothesis of this study, that the two resin cements provided proper cementation of glass fiber post, regarding the push-out bond strength, was accepted, since there were no significant differences in bond strength between the resin cements.

The advantages of adhesive cementation in the restoration of tooth with loss of structure are well established. Based on this, the use of resin cements had been proposed for the cementation of post cores $[1,6]$. However, some aspects related to the canal root dentin are unclear because of some failures observed in clinical practice $[20,24,25]$.

The push-out bond strength of glass fiber posts luted with two resin cements (Rely $\mathrm{X}^{\mathrm{TM}}$ ARC and Allcem) was analyzed and compared in different thirds of a standard length of canal roots. This test is based on the shearing stress of dentincement interfaces and it can be compared with clinical situations $[6,23]$. According to Goracci et al. [16], the push-out test is considered the most effective and reliable analysis to measure the bond strength of core posts to root canals, when compared to microtensile test.

As mentioned, one of the critical aspects of the cementation of glass fiber posts is the type of resin cement, since there is a great variety of resin cements available in the dentistry market and the product quality is essential in bonding processes [7,17,26]. According to Macedo et al. [1] and Aksornmuang et al. [9], the shear bond strength in the dentin surface is affected by the mechanical properties of resin cements.

In this study, there was no significant difference in the bond strength (MPa) between Allcem and RelyX ARC cements. This fact might be associated to their polymerization (dualcuring), chemical composition, and the same technical for cementation processes [11].
Macedo et al. [1] and Ceballos et al. [8] affirmed that dual-cured resin cements combine favorable properties of both types of resin cements - light- and self-cured resin cements - for glass fiber posts cementation. Despite selfcured cements are not affected by the distance between the activating light tip and apical region of the root, these cements have the disadvantage of low curing time in the cementation process of fiber posts. Regarding light-cured resin cements have a controlled curing time but this type of cement have a problem of light loss through the root length reducing the degree of cure and their mechanical properties.

The resin cement systems (Allcem and Rely X ARC) showed higher bond strength in the cervical third (9.88 MPa) than medium (7.2 $\mathrm{MPa)}$ and apical (5.2 MPa) thirds. These results are in agreement to Calixto et al. [6]. These authors attributed this fact to the difficulty of curing in the deepest portion of the root (medium and apical) because of the distance between the activating light tip positioned above the cervical third.

However, Edemir et al. [22] verified that there is a great variation between the direction of the dentin tubules in cervical, medium and apical thirds and in the intertubular quantity among these thirds, which increases the mechanical resistance of adhesive systems and makes it difficult to rupture the bonding. These authors showed that the hybrid layer is more uniform in the first thirds of the root canal. In the apical region, there are great irregularities in dentin morphology, i.e. presence of accessories roots, areas of resorption, and areas that had tissues depositions, pulpar calcifications and varied quantity of secondary dentin which affects the diffusion of secondary adhesives and the formation of an effective hybrid layer.

Besides, the friction of glass fiber posts to the canal root dentin increases the resistance to their displacement. Therefore, a sequence of burs 
with diameter and taper similar to the glass fiber posts may diminish bonding failures in the postcement-dentin interface $[1,27]$.

In this study, the cervical third showed the higher bond strength results. This fact may be associated with the use of a double-tapering system (White Post DCE) and its respective burs with the same diameter and thickness creating minimal post space and a lower quantity of resin cement diminishing the shrinkage after polymerization [1].

To Mallmann et al. [20], the shrinkage phenomenon that occurs in the post space after the curing process is the factor that influences the most in the bond strength results. This phenomenon may affect the bonding levels in the different thirds of root canal depending on post space shape of each third.

Bonfante et al. [7] affirmed that the cavity design ( $C$ factor) in root canals may be 40 times higher, when compared to direct restorations with the same thickness of the resin. This fact can be explained because there is a greater area of resin cement adhered to the dentin root canal and to the glass fiber post, and there is no free area to compensate the shrinkage after curing [20].

This study showed higher percentages of adhesive failures in the cement-dentin interface, followed by mixed failures (adhesive between resin cement to dentin, and cohesive in the cements). These results were also found by Kececi et al. [23] and Bonfante et al. [7]. According to Kececi et al. [23], adhesive failures are correlated to a low value of resin cement's bonding with the dentin root canal, and it can be associated to shrinkage after curing. Possibly, an application of a silica coating might provide greater bonding of the post-cement interface [7].

According to the results of this study and literature review, it can be inferred that the cementation of glass fiber posts in dentin root canals requires some careful procedures because of the technique's sensibility, type of resin cement used and the C-factor, which can affect bonding process [7,9-11]. These findings demonstrate that more in vitro or randomized clinical studies are required to evaluate long-term results of the techniques and materials evaluated.

\section{CONCLUSION}

There were no significant differences in bond strength between the two tested resin cements (AllCem and Rely X ARC). Therefore, it can be concluded that both resin cements are indicated in the cementation of glass fiber post.

\section{REFERENCES}

1. Macedo VC, Faria e Silva AL, Martins LR. Effect of cement type, relining procedure, and length of cementation on pull-out bond strength of fiber posts. J Endod. 2010 Sep;36(9):1543-6. doi: 10.1016/j.joen.2010.04.014

2. Artopoulou I, O'Keefe K L, Powers JM. Effect of core diameter and surface treatment on the retention of resin composite cores to prefabricated endodontic posts. J Prosthodont. 2006 MayJun;15(3):172-9.

3. Aleisa K, Alghabban R, Alwazzan K, Morgano SM. Effect of three endodontic sealers on the bond strength of prefabricated fiber posts luted with three resin cements. J Prosthet Dent. 2012 May;107(5):322-6. doi: 10.1016/S0022-3913(12)60084-5.

4. Hedge J, Ramakrishna, Bashetty K, Srirekha, Lekha, Champa. An in vitro evaluation of fracture strength of endodontically treated teeth with simulated flared root canals restored with different post and core systems. J Conserv Dent. 2012 Jul;15(3):223-7. doi: 10.4103/0972-0707.97942.

5. Balbosh A, Kern N. Effect of surface treatment on retention of glassfiber endodontic posts. J Prosthet Dent. 2006 Mar;95(3):218-23.

6. Calixto LR, Bandéca MC, Clavijo V, Andrade MF, Vaz LG, Campos EA. Effect of resin cement system and root region on the push-out bond strength of a translucent fiber post. Oper Dent. 2012 JanFeb;37(1):80-6. doi: 10.2341/11-035-L.

7. Bonfante G, Kaizer OB, Pegoraro LF, do Valle AL. Tensile bond strength of glass fiber posts luted with different cements. Braz Oral Res. 2007 Apr-Jun;21(2):159-64.

8. Ceballos L, Garrido MA, Fuentes V, Rodríguez J. Mechanical characterization of resin cements used for luting fiber posts by nanoindentation. Dent Mater. 2007 Jan;23(1):100-5.

9. Aksornmuang J, Nakajima M, Foxton RM, Tagami J. Mechanical properties and bond strength of dual-core resin composites to root canal dentin. Dent Mater. 2007 Feb;23(2):226-34.

10. Michida SMA, Dal Piva AMO, Tribst JPM, Souza ROA, Lombardo GHL, Bottino MA, et al. Resin push-out bonding strength to root canal detin: effect of the irrigation solution application prior to post cementation. Braz Dent J. 2017;20(2):85-92. 
11. Silva RA, Coutinho M, Cardozo PI, Silva LA, Zorzatto JR. Conventional dual-cure versus self-adhesive resin cements in dentin bond integrity. J Appl Oral Sci. 2011 Aug;19(4):355-62.

12. Pelegine RA, De Martin AS, Cunha RS, Pelegrine AA, da Silveira Bueno CE. Influence of chemical irrigants on the tensile bond strength of an adhesive system used to cement glass fiber posts to root dentin. Oral Surg Oral Med Oral Pathol Oral Radiol Endod. 2010 Nov;110(5):e73-6. doi: 10.1016/j.tripleo.2010.05.005.

13. Ayad MF, Farag AM, Garcia-Godoy F. Effect of lactic acid irrigant on shear bond strength of Epiphany adhesive sealer to human dentin surface. Oral Surg Oral Med Oral Pathol Oral Radiol Endod. 2010 May;109(5):e100-6. doi: 10.1016/j.tripleo.2009.12.050.

14. Gu XH, Mao CY, Kern M. Effect of different irrigation on smear layer removal after post space preparation. J Endod. 2009 Apr;35(4):583-6. doi: 10.1016/j.joen.2009.01.006.

15. Pérez-Heredia M, Ferrer-Luque CM, González-Rodríguez MP. The effectiveness of different acid irrigating solutions in root canal cleaning after hand and rotary instrumentation. J Endod. 2006 0ct;32(10):993-7.

16. Goracci C, Tavares AU, Fabianeli A, Monticelli F, Raffaelli 0, Cardoso $\mathrm{PC}$, et al. The adhesion between fiber posts and root canals walls: comparison between microtensile and push-out bond strength measurements. Eur J Oral Sci. 2004 Aug;112(4):353-61.

17. Aboud-Id LR, Morgan LF, Silva GA, Poletto LT, Lanza LD, Albuquerque RC. Ultrastructural evaluation of the hybrid layer after cementation of fiber posts using adhesive systems with different curing modes. Braz Dent J. 2012;23(2):116-21.

18. Kalkan M, Usumez A, Ozturk NA, Belli S, Eskitascioglu G. Bond strength between root dentin and three glass-fiber post systems. J Prosthet Dent. 2006 Jul;96(1):41-6.

19. Lopes GC, Ballarin A, Baratieri LN. Bond strength and fracture analysis between resin cements and root canal detin. Aust Endod J. 2012 Apr;38(1):14-20. doi: 10.1111/j.1747-4477.2010.00262.x.
20. Mallmann A, Jaques LB, Valandro LF Mathias P, Muench A. Microtensile bond strength of light- and self-cured adhesive systems to intraradicular dentin using a translucent fiber post. Oper Dent. 2005 Jul-Aug;30(4):500-6.

21. Campos RE, Soares CJ, Quagliatto PS, Soares PV, de Oliveira OB Jr, Santos-Filho PC, et al. In vitro study of fracture load and fracture pattern of ceramic crowns: a finite element and fractography analysis. J Prosthodont. 2011 Aug;20(6):447-55. doi: 10.1111/j.1532849X.2011.00744.x.

22. Erdemir U, Mumcu E, Topcu FT, Yildiz E, Yamanel K, Akyol M. Micro push-out bond strengths of 2 fiber post types luted using different adhesive strategies. Oral Surg Oral Med Oral Pathol Oral Radiol Endod. 2010 0ct;110(4):534-44. doi: 10.1016/j.triple0.2010.05.049.

23. Kececi AD, Kaya BU, Adanir N. Micro push-out bond strengths of four fiber-reinforced composite post systems and 2 luting materials. Oral Surg Oral Med Oral Pathol Oral Radiol Endod. 2008 Jan;105(1):121-8.

24. Cecchin D, de Almeida JF, Gomes BP, Zaia AA, Ferraz CC. Effect of chlorhexidine and ethanol on the durability of the adhesion of the fiber post relined with resin composite to the root canal. J Endod. 2011 May;37(5):678-83. doi: 10.1016/j.joen.2011.01.007.

25. Albashaireh ZS, Ghazal M, Kern M. Effects of endodontic post surface treatment, dentin conditioning, and artificial aging on the retention of glass fiber-reinforced composite resin posts. J Prosthet Dent. 2010 Jan;103(1):31-9. doi: 10.1016/S00223913(09)60212-2.

26. Grande da Cruz FZ, Grande CZ, Roderjan DA, Galvão Arrais CA, Bührer Samra AP, Calixto AL. Effect of etch-and-rinse and selfetching adhesive systems on hardness uniformity of resin cements after glass fiber post cementation. Eur J Dent. 2012 Jul;6(3):24854.

27. Amaral M, Santini MF, Wandscher V, Amaral R, Valandro LF. An in vitro comparison of different cementation strategies on the pull-out strength of a glass fiber post. Oper Dent. 2009 JulAug;34(4):443-51. doi: 10.2341/08-113.

\section{Blanca Liliana Torres León (Corresponding address)}

Department of Prosthodontics, Bahia Federal University (UFBA). Araújo Pinho Avenue, 72. ZIP: 40110 912, Salvador, Bahia, Brazil.

Phone: 55-74-1411857 / 55-71-91584084. 